\title{
Confirmation of GUS (uidA) and Cry1Ac Gene Transformation in Cotton (Gossypium hirusutum L.) Cultivars by GUS Histochemical Assay and PCR Analysis
}

\author{
Baig Rehana Sajid, A. Bharose Achyut* and Narode Vishal Devidas
}

\author{
Department of Plant Biotechnology, College of Agril Biotechnology, Latur- 413512, \\ Vasantrao Naik Marathwada Krishi Vidyapeeth, Maharashtra, India \\ *Corresponding author
}

\author{
A B S T R A C T
}

\section{Keywords}

Agrobacterium tumifaciens, transformation, Cotton, Shoot apex, $\beta$-glucoronidase (GUS).

\section{Article Info}

Accepted: 04 April 2017 Available Online: 10 May 2017
The purpose of this study was to develop an efficient protocol for genotype independent gene transformation in cotton (Gossypium hirusutum) a worldwide commercially important fibre crop, to reduce the adverse impact of harmful chemicals used to control biotic stress. Most cotton varieties remain recalcitrant and amenable to genetic manipulation to protocols so far developed. The commercially significant Indian cotton cultivars NH-615 and NH-635 were successfully transformed using shoot apex as explants. Shoot apices were aseptically isolated from 6 day old seedlings and co cultivated with Agrobacterium tumifaciens strain EHA 105 harbouring the recombinant vector pCAMBIA containing Cry1Ac gene under control of CaMV 35S promoter; neomycin phosphotransferase (nptII) gene as selectable marker. Inoculated explants were placed for two days on co cultivation medium. Transformed shoots were selected on MS (Murashige and Skoog 1962.) basal medium supplemented with $75 \mathrm{mg} / \mathrm{l}$ kanamycin and 200mg/l cefotaxime. Multiple shoots subsequently regenerated on MS $+0.5 \mathrm{mg} / \mathrm{l} \mathrm{BAP}$ resulted in high kanamycin resistant multiple shoot induction (16.5 and 13 plants of NH-615 and NH635 respectively by applying RBD statistical analysis). A total 40 explants were cultured under each treatment in 4 replications. At the same time a tissue culture independent Agrobacterium mediated in planta transformation protocol was followed to overcome recalcitrance in cotton regeneration. Germinating seedlings of NH-615 with just emerging plumules were inoculated with a separate strain of Agrobacterium LBA4404 carrying gene construct PBI121 that carries GUS ( $\beta$-glucoronidase) and selectable marker gene nptII to confirm the transformability of the cultivar. Maximum of the germinated plants were positive for GUS showing either tissue specific expression or blue spots in at least one plant part. Callus derived from cotyledonary nodes of NH-615 also showed transformation efficiency by blue colour formation in GUS histochemical analysis. This research is the foremost and successful transformation protocol for the genetic improvement of university developed cotton cultivar NH-615 and NH-635 and this protocol will be useful to research students as well as cotton breeders to develop biotic stress resistant cotton which is one of the important perspectives of AICRP under Cotton Research Station Nanded, VNMKV Parbhani.

\section{Introduction}

Cotton is an excellent natural source of textile fibre and is cultivated worldwide. It is a crop of significant value throughout the world because it is not only a source of natural fibre but also an oilseed crop. Because of its high economic importance considerable attention has been paid to improve cotton plants by conventional breeding methods (Agarwal et 
al., 1997). Genetically modified insect and herbicide resistant cotton crops have been proved be commercially valuable demonstrated by increasing acreage under transgenic cotton crop. The traditional control of insect pests has been in operation by the extensive use of chemical pesticides, which have led to severe environmental problems (Benedict and Altman, 2001). Plant cell, tissue culture and genetic engineering of plants have contributed significantly to crop improvement and production of high quality planting material but these biotechnological approaches pose problem in development of plants as they are genotype dependent and reproducible protocols have not been worked out for most elite cotton cultivars (Ratna Kumaria, 2003). Transformation of elite genotypes is desirable (Katageri et al., 2007). The transformation of cotton via Agrobacterium is a simple and efficient method of choice. Cotton transformation via Agrobacterium was first reported by Firozabady et al., (1987)and Umbeck et al., (1987). The introduction of desired genes into cotton is by no means an easy task (Leelavathi, 2003). Genotype dependent transformation capacity makes cotton more problematic (Ozyigit et al., 2007). Successful efforts to transform elite genotypes by alternate methods have been reported. Satyavathi et al., (2002) have reported genetic transformation of two Indian genotypes of cotton using shoot apices. A more efficient and detailed procedure is described here and all possible efforts have been practiced to standardise genotype independent Agrobacterium mediated transformation protocol using shoot apices as explants. Use of Agrobacterium vector is technically simple and gene transfers are often low copy, permanent and heritable as compared to biolistic method of gene transfer. In this study the shoot apex explants used for transformation were cocultivated with a super virulent strain of Agrobacterium tumifaciens and cultured on plane MS, without any hormone to permit native development in the shoot apices allowing regeneration to be plant driven and genotype independent following the protocol of Gould and Magallanes (1998). For multiple shoot regeneration the explants are sub cultured to MS supplemented with $0.5 \mathrm{mg} / \mathrm{l}$ BAP. Incidence of genetic mutation and somaclonal variation was low in plants regenerated from shoots. Successful transformation of Cry 1 AC gene and GUS reporter gene are confirmed by PCR analysis and histochemical assay respectively.

\section{Materials and Methods}

\section{Shoot isolation and Preculture}

Shoot apices from 6 day old germinating seedlings were aseptically isolated and precultured on MS+ kin $(0.1 \mathrm{mg} / \mathrm{l})$ Gould and Maria Magallanes (1998) to ensure activation of cell division in apical meristematic tissues. (Fig 2)

\section{Callus culture}

Cotyledonary node explants of NH-615 excised from 7 to 11 days old in vitro grown seedlings. $\mathrm{CN}$ explants scratched from one side with sterilised scalpel to expose maximum surface available for callus induction. Such explants were cultured on MS using five different media combinations for callus induction. Calluses were sub cultured on fresh media after 3 to 4 weeks regularly.

\section{Agrobacterium mediated gene transformation}

During the present investigation Agrobacterium mediated GUS gene transformation by in planta method of cocultivation and Cry 1 Ac gene transfer by in vitro co culture with shoot apex explants was carried out. The results of transformation 
were statistically analysed by applying RBD. (Randomised Block Design)

\section{Vector}

The disarmed Agrobacterium strain EHA-105 harbouring binary vector pCAMBIA carrying Cry 1 AC gene linked to CaMV $35 \mathrm{~S}$ promoter, OCS terminator and nos gene under control of (nos) promotor was used as selectable marker. This construct was kindly provided by Prof A.A. Bharose procured from NRCPB, IARI, New Delhi.

\section{Plasmid construct for GUS ( $\beta$ glucoronidase) reporter gene}

Bacterial strain and vector: Agrobacterium tumifaciens strain LBA 4404 harbouring binary vector pBI- 121 was used for in planta transformation of CV-NH615. The vector contains the uid $A$ reporter gene driven by CaMV $35 \mathrm{~S}$ promotor and neomycin phosphotransfsrase II (nptII) gene driven by nos (nopaline synthase) promotor. The reporter gene PBI 121 is a version of uid $A$ that lacks the bacterial ribosome binding site and shows no expression in Agrobacterium but good expression in plant cells.

\section{Transformation procedure}

\section{Confirmation of transforming efficiency by reporter gene}

The Agrobacterium strain EHA 105 containing Cry 1 Ac was maintained on solid YEMA medium containing Kanamycin @ $50 \mathrm{mg} / 1$ and rifampicin @ 50mg/l by sub culturing once in every $30-40$ days on fresh medium and incubated at $28^{\circ} \mathrm{C}$ temperature for 48 hours. The seedlings with just emerging plumules were infected by separating the cotyledons without damaging them such that the meristem is visible and then pricked at meristem with a sterile syringe needle and subsequently dunked in Agrobacterium cell suspension grown to late log phase (OD at $660 \mathrm{~nm}=0.6-0.8)$. Following infection the seedlings were washed gently with sterile water and later transferred to autoclaved vermiculite moistened with water for germination in wide mouth capped jars of $300 \mathrm{ml}$ capacity, 5 seeds per jar. After 5 to 6 days the seedlings were transferred to soilrite in pots and were allowed to grow under growth room condition $\left(26-28{ }^{\circ} \mathrm{C}\right.$ under a 14 hour photoperiod with fluorescent light of intensity $35 \mu \mathrm{molm}^{-2} \mathrm{~s}^{-1}$.)

\section{GUS gene transfer to Callus}

25 days old callus of $\mathrm{NH}-615$ was infected with the Agrobacterium strain carrying uid $A$ gene following the same procedure as mentioned for Cryl Ac gene transfer. The infection period was optimized from $30 \mathrm{sec}$ to 30 mint (Table 2). After cocultivation in darkness for $48 \mathrm{~h}$ at $21^{\circ} \mathrm{C}$, the $\mathrm{CN}$ callus were rinsed thoroughly with $200 \mathrm{mg} / \mathrm{l}$ cefotaxime in sterile water prior to inoculating to shoot induction media.

\section{Cry 1 Ac gene transfer procedure}

Shoot apex explants aseptically isolated from 6 day old germinating seedlings and precultured were dipped in Agrobacterium cell suspension grown to late log phase (OD at $660 \mathrm{~nm}=0.6$ to0.8). Shoot apices were gently shaken in bacterial suspension to ensure contact, blot dried, placed on filter paper and were subsequently transferred to MS media for cocultivation for two days. After cocultivation explants are washed with $200 \mathrm{mg} / \mathrm{l}$ cefotaxime to remove the excessive growth of Agrobacterium. Then the explants were cultured on $\mathrm{MS}+0.5 \mathrm{mg} / \mathrm{l} \mathrm{BAP}$ and $200 \mathrm{mg} / \mathrm{l}$ cefotaxime for induction of multiple shoots. The sub culturing was done every two days to completely remove the excess of Agrobacterium growth. 


\section{Molecular characterization of transgenic plants}

Total genomic DNA was extracted from young leaves of putative transformants using standard CTAB method of Seghai and Marof (1984). PCR was performed in a total reaction mixture volume of $25 \mu \mathrm{l}$ consisting of $10 \mathrm{X}$ reaction buffer, $25 \mathrm{ng} / \mathrm{ml}$ of DNA template $25 \mathrm{mM} \mathrm{MgCl}_{2}, 10 \mathrm{mM}$ of each the dNTPs, $0.4 \mu \mathrm{M}$ of each primers and $3 \mathrm{U} / \mu \mathrm{l}$ of Taq polymerase and adding water to make up 20 $\mu 1$. PCR was carried out in thermal cycler in following steps. Initial denaturation at $94^{0} \mathrm{C}$ for 5 mint, then 35 cycles of denaturation at $94^{\circ} \mathrm{C}$ for $45 \mathrm{sec}$, annealing at $56^{\circ} \mathrm{C}$ for $45 \mathrm{sec}$, extending at $72^{\circ} \mathrm{C}$ for $30 \mathrm{sec}$ and finally extending at $72^{0} \mathrm{C}$ for $10 \mathrm{~min}$. Amplified products were subjected to gel electrophoresis by $0.1 \%$ agar $(\mathrm{w} / \mathrm{v})$ agarose gel. The sequence of Cryl AC specific primers used for confirming transgenics was

F 5' GGA GTG GGA GTG GCG TTT GGC CTG

R 3' CCA GTT TGT TGG AAG GCA ACT $\mathrm{CCC}$

\section{GUS Histochemical Assay}

Phenotypic GUS expression was determined by histochemical GUS assay. A total of 120 $\mathrm{T}_{0}$ plants of NH-615 analysed by incubating the different plant parts isolated from the putative transformants produced on vermiculite. Plant tissues were incubated overnight at $37^{\circ} \mathrm{C}$ in $\mathrm{X}$-Gluc solution and next day soaked with $75 \%$ ethanol to clear the chlorophyll. X-Gluc solution consists of $1 \mathrm{mM}$ X-Gluc (5 bromo, 4 chloro 3 indolyl $\beta$-D glucoronic acid) in 50mM Na $2 \mathrm{HPO}_{4}(\mathrm{PH} 7.0)$ and $0.1 \%$ Trition $\mathrm{X}-100$ (Jefferson et al 1987). Young leaves and hypocotyles of the transgenic plants were randomly selected. The slides were then observed under microscope in $40 \mathrm{X}$ magnification.

\section{Results and Discussion}

In vitro germination and callus formation

Both the genotypes NH-615 and NH-635 showed high germination percentage $98 \%$ and $95 \%$ respectively on hormone free MS media. Cotyledonary nodes excised from 6 day old in vitro germinating seedlings tested on various kinetin and 2, 4-D combinations. Among these high frequency $(70 \%)$ embryonic callus development was obtained following culture of explants on MS medium supplemented with kin $(0.5 \mathrm{mg} / \mathrm{l})$ and 2 , 4-D $(0.5 \mathrm{mg} / \mathrm{l})$. (Table 1) (Fig 6 a)

\section{GUS gene transfer to Callus}

Calluses showing high growth rate were selected on MS+ Kan (75mg/l). It has been observed that as infection period increases gradually callus survival and transformation rate decrease. The infection period of $30 \mathrm{sec}$ was found best for successful delivery of GUS gene in cv.NH-615. (Table 2)(Fig 6 b)

\section{Results of In planta GUS gene transfer}

The infection period for Agrobacterium mediated in planta gene transfer was optimized from $60 \mathrm{~min}$ in decreasing level up to to $15 \mathrm{~min}$. Among those $60 \mathrm{~min}$ was found best (Table 3). Seedlings showing high growth rate were used for histochemical analysis to estimate transformation efficiency. Histochemical GUS assay revealed expression of GUS gene in hypocotyledonary nodes and leaves of transgenic $\mathrm{T}_{0}$ plants. Sections of tissues, plant parts treated with $\mathrm{X}$ Gluc solution revealed expression of uid gene within the cells (Fig 8 a, b,c and d) clearly showing the transgene expression at random locations within leaf cells indicating possibility of stable transformants in next generation. 
Agrobacterium mediated Cry 1 Ac gene transfer

Agrobacterium and explant coculture period was optimised from $4 \mathrm{~min}$ to $30 \mathrm{~min}$. In contrast to in planta GUS gene transfer a short duration of Agrobacterium infection was found more feasible for in vitro insertion of Cryl Ac gene into cotton genome.

\section{Kanamycin sensitivity test}

Precultured shoot apices transformed with Agrobacterium strain carrying Cryl Ac were screened by kanamycin sensitivity test using different concentrations (Table 4) showed highest response to multiple shoot induction on MS $+0.5 \mathrm{mg} / 1$ BAP. (Fig 3 and 4) Following the protocol standardised by us for successful cotton regeneration. Precultured shoot apices were used for transformation as it shows better response to shoot induction due to actively dividing meristematic cells. Maximum Kanamycin resistant plants produced at $4 \mathrm{~min}$ cocultivation. The two cultivars NH-615 and NH-635 have produced 16.2 and 13 survival rate on kan $(75 \mathrm{mg} / \mathrm{l})$. It has been observed that as infection period increases gradually plant survival and transformation rate decreases. (Table 5) Screened plants are transferred to multiple shoot induction media after that leaves were used for PCR.

Table.1 Response of cotyledonary node for callusing of cotton cv.NH-615

\begin{tabular}{|l|l|c|c|c|}
\hline Media & Composition & No of explants & $\begin{array}{l}\text { No of explants } \\
\text { responded }\end{array}$ & $\begin{array}{l}\text { Callusing } \\
\text { percentage }\end{array}$ \\
\hline CI & $\begin{array}{l}\text { MS+2,4-D } \\
0.1 \mathrm{mg} / \mathrm{l}+\mathrm{kin} 0.1 \mathrm{mg} / \mathrm{l}\end{array}$ & 10 & 4 & 40 \\
\hline C2 & $\begin{array}{l}\text { MS+2,4-D } \\
0.2 \mathrm{mg} / \mathrm{l}+\mathrm{kin} 0.2 \mathrm{mg} / \mathrm{l}\end{array}$ & 10 & 3 & 30 \\
\hline C3 & $\begin{array}{l}\text { MS+2,4-D } \\
0.3 \mathrm{mg} / \mathrm{l}+\mathrm{kin} 0.3 \mathrm{mg} / \mathrm{l}\end{array}$ & 10 & 4 & 40 \\
\hline C4 & $\begin{array}{l}\text { MS+2,4-D } \\
0.4 \mathrm{mg} / \mathrm{l}+\mathrm{kin} 0.4 \mathrm{mg} / \mathrm{l}\end{array}$ & 10 & 6 & 60 \\
\hline C5 & $\begin{array}{l}\text { MS+2,4-D } \\
0.5 \mathrm{mg} / \mathrm{l}+\mathrm{kin} 0.5 \mathrm{mg} / \mathrm{l}\end{array}$ & 10 & 7 & 70 \\
\hline
\end{tabular}

Table.2 GUS gene expression in callus of cv.NH-615

\begin{tabular}{|l|l|l|l|l|l|l|}
\hline Serial No & $\begin{array}{l}\text { Inoculation } \\
\text { period }\end{array}$ & $\begin{array}{l}\text { No of } \\
\text { callus } \\
\text { inoculated }\end{array}$ & $\begin{array}{l}\text { No of } \\
\text { callus } \\
\text { shown } \\
\text { growth }\end{array}$ & $\begin{array}{l}\text { Screening } \\
\text { on } \\
\text { kanamycin } \\
(75 \mathrm{mg} / \mathrm{l})\end{array}$ & $\begin{array}{l}\text { No of } \\
\text { callus } \\
\text { Survived }\end{array}$ & $\begin{array}{l}\text { No of } \\
\text { callus } \\
\text { showed } \\
\text { positive } \\
\text { GUS assay }\end{array}$ \\
\hline 1 & $30 \mathrm{sec}$ & 40 & 32 & & 18 & 06 \\
\hline 2 & $1 \mathrm{~min}$ & 40 & 28 & & 11 & 04 \\
\hline 3 & $2 \mathrm{~min}$ & 40 & 23 & & 03 & 02 \\
\hline 4 & $30 \mathrm{~min}$ & 40 & 05 & & 00 & 00 \\
\hline
\end{tabular}


Table.3 GUS gene transformation analysis

\begin{tabular}{|l|l|}
\hline Treatments & GUS assay analysis \\
\hline $60 \mathrm{~min}$ & 8.0 \\
\hline $45 \mathrm{~min}$ & 6.2 \\
\hline $30 \mathrm{~min}$ & 3.0 \\
\hline $15 \mathrm{~min}$ & 0.0 \\
\hline $\mathrm{SE}$ & 0.22 \\
\hline $\mathrm{CD}$ & 0.69 \\
\hline
\end{tabular}

(Note: A total of 40 explants were cultured under each treatment in four replications)

Table.4 Effect of different concentrations of Kanamycin on the Cotton explants

\begin{tabular}{|l|l|l|}
\hline Sr. No. & Treatment of Kan. mg/l & Explants after 2 weeks \\
\hline $\mathbf{1}$ & Control & + \\
\hline 2 & 25 & + \\
\hline 3 & 50 & + \\
\hline 4 & 75 & - \\
\hline 5 & 100 & - \\
\hline
\end{tabular}

+ = survived; - = died

Table.5 Analysis of results of Agrobacterium mediated Cryl Ac gene transfer

\begin{tabular}{|c|c|c|}
\hline $\begin{array}{l}\text { Duration of co-cultivation } \\
\text { of Agrobacterium with the } \\
\text { explants (shoot apices) }\end{array}$ & $\begin{array}{l}\text { No. of plants on Kanamycin } \\
(600 \mathrm{mg} / \mathrm{l} \text { conc. }) \mathrm{cv} \text {. NH-615 }\end{array}$ & $\begin{array}{l}\text { No.of plants on Kanamycin } \\
(600 \mathrm{mg} / \mathrm{l} \text { conc.) } \mathrm{cv} \text {. NH-635 }\end{array}$ \\
\hline $04 \mathrm{~min}$ & 16.2 & 13.0 \\
\hline $10 \mathrm{~min}$ & 4.0 & 4.0 \\
\hline $20 \mathrm{~min}$ & 0.0 & 0.0 \\
\hline $30 \mathrm{~min}$ & 0.0 & 0.0 \\
\hline $\mathrm{SE}$ & 0.35 & 0.20 \\
\hline $\mathrm{CD}$ & 1.09 & 0.62 \\
\hline
\end{tabular}

(Note: A total of 40 explants were infected each time under each treatment in four replications) 
Table.6 In vitro transformation studies using Cryl Ac in cotton cv.NH-615

\begin{tabular}{|l|l|l|l|l|l|l|l|}
\hline $\begin{array}{l}\text { Serial } \\
\text { No }\end{array}$ & $\begin{array}{l}\text { Colonization } \\
\text { period }\end{array}$ & $\begin{array}{l}\text { No of } \\
\text { explants } \\
\text { cocultivated }\end{array}$ & $\begin{array}{l}\text { No of } \\
\text { explants } \\
\text { died }\end{array}$ & $\begin{array}{l}\text { No of } \\
\text { explants } \\
\text { survived }\end{array}$ & $\begin{array}{l}\text { No of } \\
\text { explants } \\
\text { on kan } \\
75 \mathrm{mg} / 1 \\
\text { conc. }\end{array}$ & $\begin{array}{l}\text { No of } \\
\text { explants } \\
\text { PCR } \\
\text { positive }\end{array}$ & $\begin{array}{l}\text { Transformation } \\
\text { frequency in } \\
\text { percent }\end{array}$ \\
\hline 1 & $4 \mathrm{~min}$ & 40 & 04 & 36 & 18 & 00 & 00.00 \\
\hline 2 & $10 \mathrm{~min}$ & 40 & 13 & 27 & 03 & 01 & 02.50 \\
\hline 3 & $20 \mathrm{~min}$ & 40 & 21 & 19 & 02 & 00 & 00.00 \\
\hline 4 & $30 \mathrm{~min}$ & 40 & 27 & 13 & 01 & 00 & 00.00 \\
\hline 5 & Total & 160 & 65 & 95 & 24 & 01 & 02.50 \\
\hline
\end{tabular}

Table.7 In vitro transformation studies using Cry1 Ac in cotton cv.NH-635

\begin{tabular}{|l|l|l|l|l|l|l|l|}
\hline Sr no & $\begin{array}{l}\text { Colonization } \\
\text { period }\end{array}$ & $\begin{array}{l}\text { No of } \\
\text { explants } \\
\text { cocultivated } \\
\text { explants } \\
\text { died }\end{array}$ & $\begin{array}{l}\text { No of } \\
\text { explants } \\
\text { survived }\end{array}$ & $\begin{array}{l}\text { No of } \\
\text { explants } \\
\text { on kan } \\
75 \mathrm{mg} / \mathrm{l} \\
\text { conc. }\end{array}$ & $\begin{array}{l}\text { No of } \\
\text { explants } \\
\text { PCR } \\
\text { positive }\end{array}$ & $\begin{array}{l}\text { Transformation } \\
\text { frequency in } \\
\text { percent }\end{array}$ \\
\hline 1 & $4 \mathrm{~min}$ & 40 & 06 & 34 & 20 & 00 & 00 \\
\hline 2 & $10 \mathrm{~min}$ & 40 & 15 & 25 & 02 & 01 & 00 \\
\hline 3 & $20 \mathrm{~min}$ & 40 & 24 & 16 & 01 & 00 & 00 \\
\hline 4 & $30 \mathrm{~min}$ & 40 & 26 & 14 & 00 & 00 & 00 \\
\hline 5 & Total & 160 & 71 & 89 & 23 & 00 & 00 \\
\hline
\end{tabular}

Fig.1 In vitro germination of cotton cultivars NH-615 and NH-635
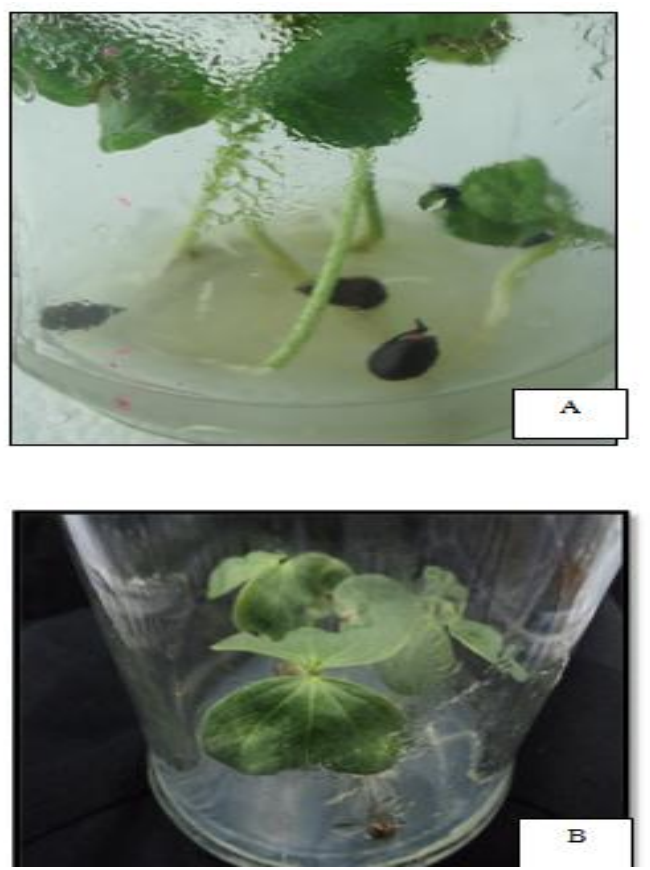
Fig.2 Preculture of explants (shoot apices) before transformation

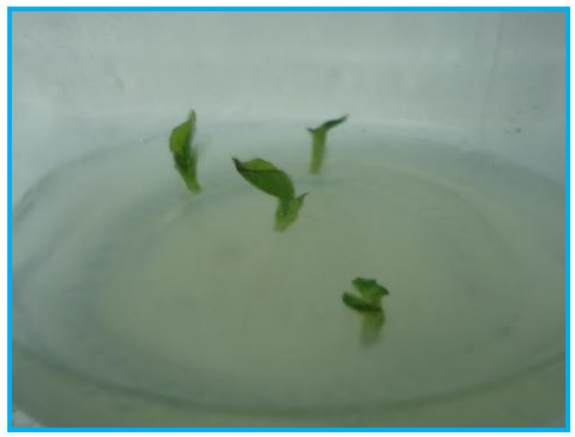

Fig.3 Multiple shoot induction in transformed explants of cv.NH-615

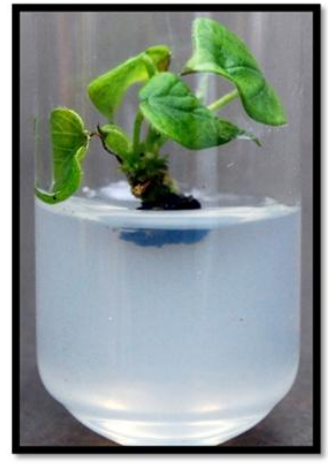

Fig.4 Multiple Shoot induction in transformed explants in cv. NH- 635

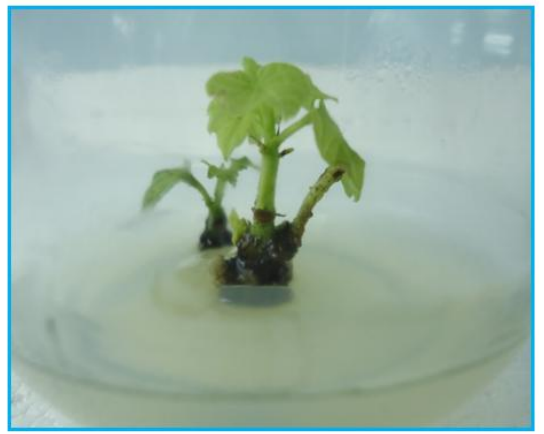

Fig.5 Tissue culture independent Agrobacterium mediated in planta GUS gene transfer to cv. NH-615. Acclimatization and hardening of transformed plantlets to sand, soil and vermiculated soil were used in 1:1:1 ratio

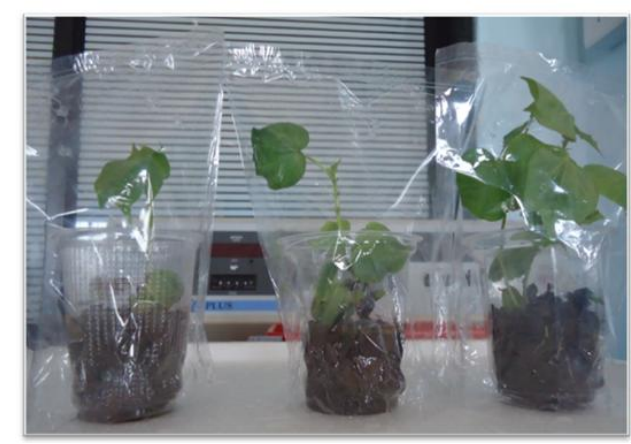


Fig.6 (a \& b): Callus induction and Histochemical GUS assay in cv. NH-615

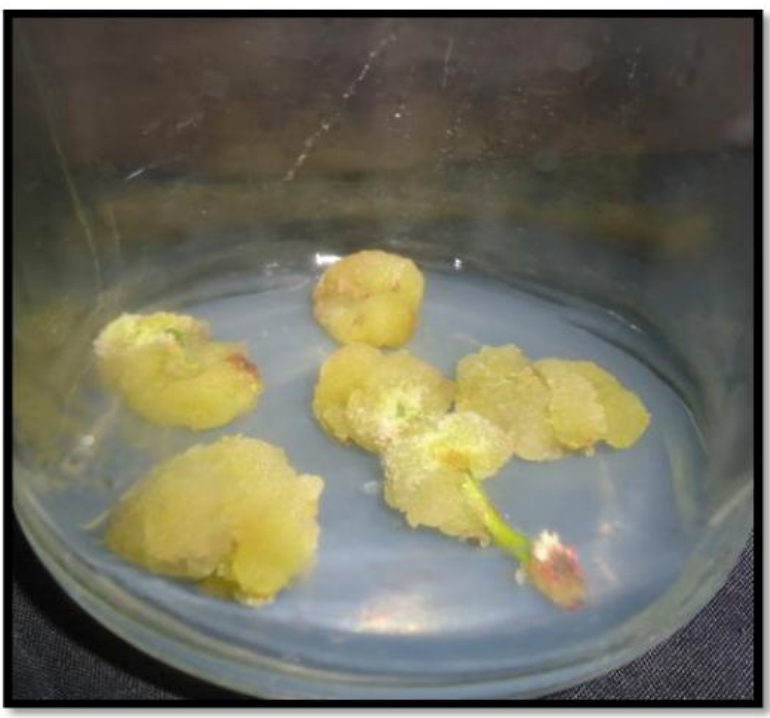

Fig 6: (a): Callus induction on medium of $c v$. NH-615
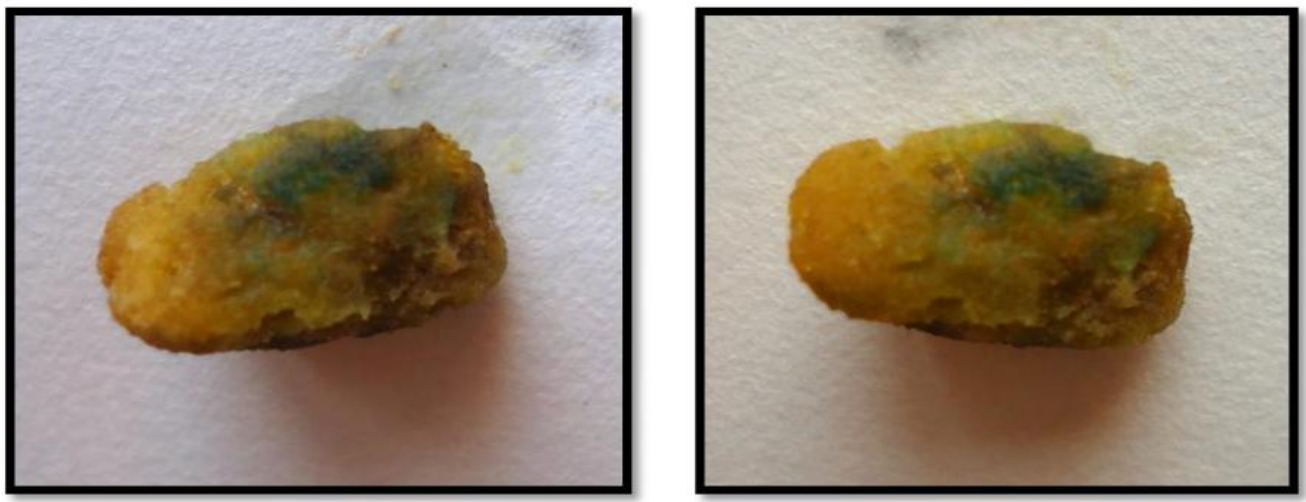

\section{Gus positive} expression

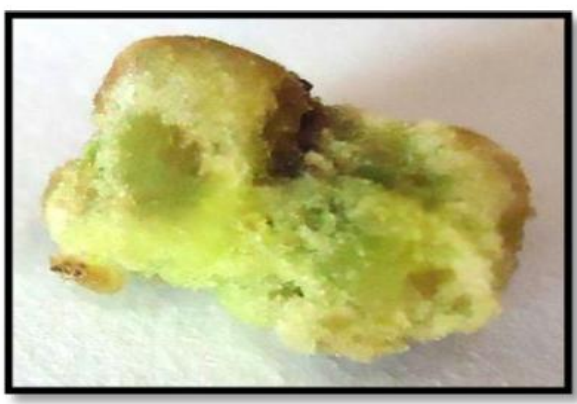

Gus positive expression

Fig 6: (b): Histochemical Gus positive expression in callus with control of cv. NH-615. 
Fig.7 (a): PCR analysis of DNA isolated from leaves of transformed cotton using primer pairs specific for Cry1Ac gene in agarose gel.

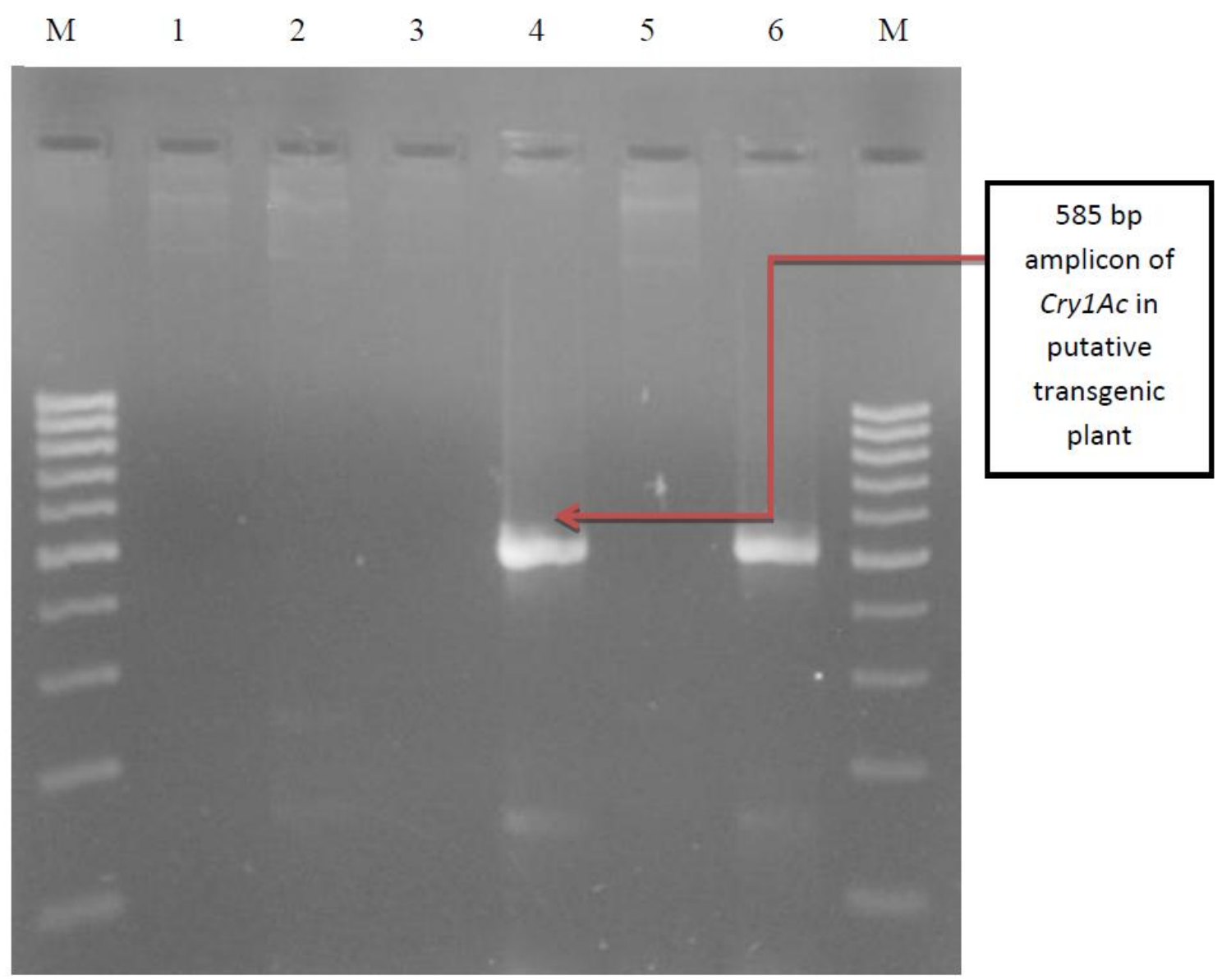

Lanes 1-4: DNA from putative transgenic cotton lines.

Lane 5: Non $B t$ sample.

Lane 6: $B t$ sample

M: 100 bp DNA ladder (Fermentas, Life sciences.India.) 
Fig.8 a, b, c and d GUS histochemical analysis of transformed T0 plants

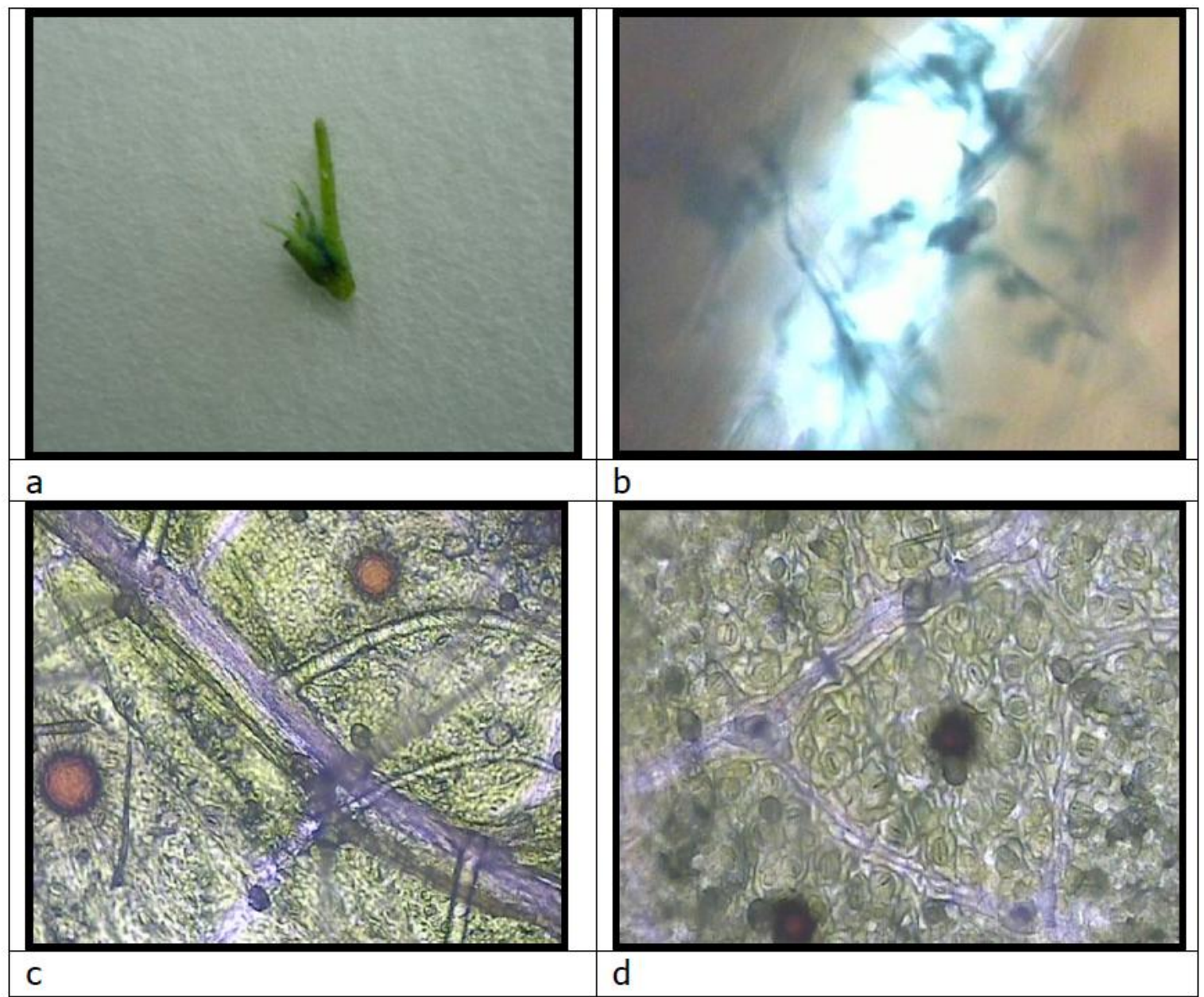

(a: Expression of GUS in hypocotyledonary node; b: Section of hypoctyledonary node observed under microscope; c: Section of leaf showing GUS gene expression within the cells; d: $G U S$ gene expression at random locations within the cell.)

Shoot tip and cotyledonary node expants both can be used in gene transfer by Agrobacterium. But shoot apices were preferred here due to better regeneration response. Total 160 explants were colonized with Agrobacterium culture containing Cryl $A c$ and then transferred to MS+BAP $(0.5 \mathrm{mg} / \mathrm{l})+250 \mathrm{mg} / \mathrm{l}$ cefotaxime (to control excessive growth of Agrobacterium.) for 2 to 3 days. Out of 160, 65 explants died when transferred to while 95 survived on shoot induction media. Survived explants were selected on 75mg/l kanamycin. Out of 95, 24 explants were viable on kanamycin selection media. These 24 explants were screened for integration of cry 1 Ac by PCR using Cryl Ac specific primers.

\section{PCR analysis}

In total 24 explants of cv.NH-615 and 23 of NH-635 were further checked for presence of transgene. Using Cryl Ac specific primers but the amplification of desired transgene was observed only in one plant of cv. NH- 615 at 2 mint colonization of 585 bp. (Fig 7). NH615 showed $2.5 \%$ transformation frequency whereas NH-635 showed zero percent as none 
of NH-635 plants found PCR positive. (Table 6 and 7) Our investigation was the first and foremost protocol standardized for successful gene delivery to local cotton cultivar of VNMKV Parbhani.

To evaluate the transient GUS frequency optimum conditions were determined. Parameters optimised include co cultivation time and seedling stage. The total no of GUS spots and GUS positive sections on different leaf and shoot parts as well as in callus were scored. The GUS positive sections are deeply stained blue regions on different plant parts such as leaves, cotyledonary nodes and stems etc.

GUS analysis revealed a wide variety of expression patterns

GUS staining was observed in leaves of putative transformants $75 \%$ in leaves $70 \%$ in callus and $60 \%$ in cotyledonary nodes while it was rare in roots. These results indicate that within a population of transformed plants expression of GUS gene occurs at high frequency in wide range of plant parts. The total no of GUS hits were more in randomly stained leaf parts than in other shoot parts. Deeply stained GUS positive section on callus were more in number which indicates that the shoot arising from these areas could be transformed.

\section{References}

Agrawal, D.C., Banerjee, R.R., Kolala, A.B., Dhage, A.V., Kulkarni, A.V., Nalawade, S.H. and Krishnamurthy, K.V. 1997. In vitro induction of multiple shoots and plant regeneration in cotton (Gossypium hirsutum L.). Plant Cell Rep., 16: 647-652.

Benedict, J.H and Altman, D.W. 2001. Commercialization of transgenic cotton expressing Insecticidal crystal protein. In: Jenkins JN, Saha $\mathrm{S}$ (eds) Genetic improvement of cotton. USDAAgricultural Research Service, Oxford \& IBH Publishing Co. Pvt. Ltd., New Delhi, India pp. 136-201.

Firoozabady, E., Deboer, D.L., Merlo, D.J., Halk, E.L., Amerson, L.N., Rashka, A.E. and Murray, E.E. 1987. Transformation of cotton (Gossypium hirsutum L.) by Agrobacterium tumefaciens and regeneration of transgenic plants. Plant Mol. Biol., 10: 105-116.

Gould, J. and Maria Magallenes-Cedeno. 1998. Adaptation of cotton shot apex to Agrobacterium mediated transformation. Plant Mol. Boil. Rep., 16: 1-10.

Gulzar, S., Sanghera, Manjit, S., Gill, Shabir H., Wani and Satbir, S., Gosal. 2011. Factors affecting transformation efficiency of shoot apices of Gossypium arboreum and Gossypium hirsutum cultivars with tumefaciens, Elixir Bio. Tech., 37: 3934-3940.

Jefferson, R.A. 1987. Assaying chimeric genes in plants, the GUS gene fusion system, Plant Mol. Biol. Rep., 5: 387405.

Katageri, I.S., H.M. Vamadevaiah, S.S. Udikeri, B.M. Khadi and P.A. Kumar. 2007. Genetic transformation of an elite Indian genotype of cotton (Gossypium hirsutum L.) for insect resistance. Curr. Sci., 93: 12-25.

Leelavathi, S., Sunnichan, V.G., Kumria, R., Vijaykanth, G.P., Bhatnagar, R.K. and Reddy, V.S. 2003. A simple and rapid Agrobacterium-mediated transformation protocol for cotton (Gossypium hirsutum L.): Embryogenic calli as a source to generate large number of transgenic plants. Plant Cell Rep.

Murashige, T. and Skoog, F. 1962. A revised medium for rapid growth bioassay with tobacco cultures. Physiologia plantarum., 15: 473-479. 
Ozyigit, I.I., M.V. Kahraman and O. Ercan. 2007. Relation between explant age, total phenols and regeneration response in tissue cultured cotton (Gossypium hirsutum L.), African J. Biotechnol., 6(1): 003-008.

Ratna kumaria, Sadhu Leelavathi, Raj K. Bhatnagar and Vanga Siva Reddy.2003. Review paper PTC, Regeneration and genetic transformation of cotton present status and future perspectives. Plant Tissue Cult., 13(2): 211-225.
Satyavathi, V.V., Prasad, V., Lakshmi, B.G. and Sita, G.L. 2000. High efficiency transformation protocol for three Indian cotton varieties via Agrobacterium tumefaciens. Plant Sci., 162: 215-22.

Seghai, Maroof, M.A., Soliman, K.M., Jorgensen, R.A., Allard, R.W. 1984. Ribosomal DNA spacer length polymorphism in barley Mendelian inheritance, chromosomal location and population dynamics. Proc. Natl. Acad. Sci., USA, 81: 8014-8019.

\section{How to cite this article:}

Baig Rehana Sajid, A. Bharose Achyut and Narode Vishal Devidas. 2017. Confirmation of GUS (uidA) and Cry1Ac Gene Transformation in Cotton (Gossypium hirusutum L.) Cultivars by GUS Histochemical Assay and PCR Analysis. Int.J.Curr.Microbiol.App.Sci. 6(5): 794-806. doi: https://doi.org/10.20546/ijcmas.2017.605.090 